\title{
EFFECT OF HUMIC ACID AND IRRIGATION WATER QUALITY ON FODDER BEET YIELD AND ITS COMPONENTS AS WELL AS SOME SOIL CHEMICAL PROPERTIES
}

\author{
Ashraf M.G. Ewis ${ }^{1 *}$, Fatma S.H. Ismail ${ }^{2}$, Walaa M.E. Mousa ${ }^{2}$ and Hend H.M. Hassan ${ }^{2}$ \\ 1. Soil and Water Dept., Fac. Technol. and Dev., Zagazig Univ., Egypt \\ 2. Forage Crop, Res. Sec., Field Crop, Res., Inst., Agric. Res. Cent., Giza, Egypt
}

Received: 10/10/2017 ; Accepted: 19/11/2017

\begin{abstract}
To study the interaction effects of humic acid rates $(\mathrm{HA}) \times$ irrigation water quality on productivity of fodder beet yield (Beta vulgaris L.) and its quality as well as some soil chemical properties, two field experiments were conducted in a split plot design with three replications in two different locations, El-Salam canal and Bahr Hadous drain in Sahl El-Hossinia, Sharkia Governorate, Egypt during to winter seasons (2014/2015 and 2015/2016). The studied factors were four rates of humic acid $\left(0,800,1600\right.$ and $2400 \mathrm{ml} \mathrm{HA}$ for $4001^{-1}$ of irrigation water i.e., $0,2,4$ and $6 \mathrm{ml} \mathrm{HA} \mathrm{l}^{-1}$, respectively) and two types of irrigation water (El-Salam canal water $1.75 \mathrm{dSm}^{-1}$ and Bahr Hadous drain water $3.31 \mathrm{dSm}^{-1}$ ). The results indicated that using each of irrigation water and humic acid rate gave the best values of all the studied characters in El-Salam canal region compared to that obtained from Bahr Hadous drain region. Concerning the interaction effect (El-Salam canal irrigation water $\times$ HA $6 \mathrm{ml} \mathrm{l}^{-1}$ rate) recorded the maximum values for all studied characters: growth attributes (root length, root diameter, fresh weight (FW), dry weight (DW), fresh yield (FY), dry yield (DY), total fresh yield (TFY) and Total dry yield (TDY) and total chlorophyll), yield quality crude protein (CP), digestible crude protein (DCP), CF, ash, fat (\%) in different organs and proline in top organs of fodder beet plants) and chemical composition (N, P, K, Fe, Mn and $\mathrm{Zn}$ concentrations and uptake) of fodder beet yield as well as some soil chemical properties ( $\mathrm{pH}, \mathrm{EC}, \mathrm{CEC}$, macro and micronutrients contents).
\end{abstract}

Key words: Humic acid, irrigation water quality, fodder beet (Beta vulgaris L.).

\section{INTRODCTION}

Fodder beet is successfully grown as a fodder crop in many Mediterranean regions. The plant is used as available source of fodder for cattle (Niazi et al., 2000). Since fodder beet contains high water and sugar, it increases milk product and is suitable forage for dairy cows. The fodder beet is used by mixing with straw in European countries and it is also suitable to make silage (Akyıldız 1983, Özen et al., 1993). Fodder beet is a new introduced crop in Egypt to be cultivated in new reclaimed lands. The salt affected soil and the poor quality water are among the problems facing this area. This crop is considered to be one of the highest salt

\footnotetext{
* Corresponding author: Tel. : +201115568334
}

E-mail address: ashrafewis@hotmail.com tolerant field crops (Maas, 1986). Fodder beet productivity depends on amount of available nutrient in the soil. This crop requires large amounts of nitrogen. Extremely high yield potential when grown on high fertile soils. Many investigators indicated that nitrogen fertilizers are one of the major costs for production of fodder beet crop (Abdel-Gwad et al., 2008; Sarhan and Ismail, 2003). Some substances as well as humic acid could be effect on chemical, physical and biological properties of the soil and improved the organic contents of soils for growing crops. Humic acid is the active constituent of organic humus, which can play a very important role in soil conditioning and plant growth. Physically, it promotes good soil 
structure and increases the water holding capacity of the soil; biologically it enhances the growth of useful soil organisms, while chemically it serves as an adsorption and retention complex for inorganic plant nutrients i.e., make many nutrient available in soil such as phosphate, calcium and trace elements (Mackowiak et al., 2001; Atiyeh et al., 2002; Leonard, 2008; Rahmat et al., 2010). Several researchers, David (1991), Padem et al. (1999), Neri et al. (2002) and El-Desuki (2004) concluded that humic acid as foliar spray enhanced growth, nutrient uptake and yield as well as improved the quality of the production of some crops, this may be save the amount of applied N,P,K to the soil and then decreases pollution and costs. Improvement of soil conditions and establishing equilibrium among plant nutrients are also important for soil productivity and plant production. Humic and organic substances improve soil characteristics and enhance plant growth significantly due to increasing cell membrane permeability, respiration, photosynthesis, oxygen and phosphorus uptake and supplying root cell growth (Varnin and Pinton, 2001; Ulukan, 2008; Pizzeghello et al., 2013).

The objective of this research was to study the effect of different rates of humic acid, irrigation water quality and their interaction on yield and yield components of fodder beet as well as some soil chemical properties.

\section{MATERIALS AND METHODS}

To investigate the effect of humic acid rate and irrigation water quality on productivity of fodder beet plants (Beta vulgaris L.) and its quality as well as some soil chemical properties, two field experiments were performed in two different locations, (El-Salam canal and Bahr Hadous drain) in Sahl El-Hossinia, Sharkia Governorates, Egypt during two winter seasons (2014/2015 and 2015/2016). Chemical and physical properties of the studied soil before sowing are presented in Tables $1 \mathrm{a}$ and $1 \mathrm{~b}$. Chemical analyses of irrigation water and humic acid are shown in Tables 2 and 3, respectively. In both seasons, each experiment was conducted in a split plot design with three replicates. The irrigation water qualities (El-Salam canal water $=1.75 \mathrm{dSm}^{-1}$ and Bahr Hadous drain water $=$
$3.31 \mathrm{dSm}^{-1}$ ) were treated as a main factor while the rates of humic acid were $0,2,4$ and $6 \mathrm{ml} \mathrm{l}^{-1}$ of irrigation water (i.e., $\mathrm{T}_{1}=0, \mathrm{~T}_{2}=800, \mathrm{~T}_{3}=$ 1600 and $\mathrm{T}_{4}=2400 \mathrm{ml} \mathrm{HA} 400 \mathrm{1}^{-1}$, respectively) were distributed at random in the sub plots. Each experimental plot was $5 \times 10 \mathrm{~m}$ divided into rows with $50 \mathrm{~cm}$ apart and $25 \mathrm{~cm}$ between hills. Fodder beet seeds (Beta vulgaris L., variety monovert) were sown on $15^{\text {th }}$ October 2014 and $20^{\text {th }}$ October 2015 seasons, respectively. The preceding crop was rice in both seasons. Thinning was done after 30 days from sowing. The recommended doses of $\mathrm{N}, \mathrm{P}$ and $\mathrm{K}$ were applied to the soil at rates of $100 \mathrm{~kg} \mathrm{~N}$ as urea $(46 \% \mathrm{~N}), 62 \mathrm{~kg} \mathrm{~K}$ as Potassium sulfate $(48 \%$ $\left.\mathrm{K}_{2} \mathrm{O}\right)$ and $13.5 \mathrm{~kg} \mathrm{P}$ as super phosphate $(15.5 \%$ $\mathrm{P}_{2} \mathrm{O}_{5}$ ) fad ${ }^{-1}$. Both humic acid (as foliar) and urea were applied in successive three times at 30, 55 and 75 days after sowing. Potassium sulfate was added to the soil in two splitting doses at 4 and 8 weeks from planting whereas; super phosphate was mixed with top soil as one dose during soil preparation before planting.

\section{Parameters of Vegetative Characters}

At harvesting on 25 May 2015 and 2016, 10 plants from the central rows were pulled to determine the growth characters and forage yield. Root length $(\mathrm{cm})=$ distance between the beginning of the root to an end, root diameter $(\mathrm{cm})=$ circumference of circle when the maximum width of root divided on 2.14 also fresh and dry yields for tops and roots $\left(\mathrm{kg}\right.$ plant $\left.{ }^{-1}\right)$ were determined.

\section{Yield Parameters and Yield Quality}

Two square meters $(1 \times 2 \mathrm{~m})$ area were harvested in each plot (Albayrak and Cama, 2006). After harvest, fresh and dry yields for tops and roots were recorded $\left(\right.$ ton $\mathrm{fad}^{-1}$ ) as well as samples were oven dried at $70^{\circ} \mathrm{C}$ to a constant weight (Martin et al., 1990). The digestion of dried samples were done to determine N, P, K, $\mathrm{Fe}, \mathrm{Mn}$ and $\mathrm{Zn}$ nutrients using the standard methods as reported in Westerman (1990). Crude protein (CP) content was calculated multiplying $\mathrm{N}$ content $\times 6.25$. Digestible crude protein $(\mathrm{DCP} \%)=[(\mathrm{CP}(\%) \times 0.929)-3.48]$ as recorded by Church (1979). Crude fiber, crude fat, ash, proline and total chlorophyll concentrations were determined according to (Albayrak et al. 2009; Türk et al. 2009). 
Table 1a. Physicochemical analyses of tested soil (El-Salam canal)

\begin{tabular}{|c|c|c|c|c|c|c|c|c|}
\hline $\begin{array}{l}\text { Coarse } \\
\text { sand } \\
(\%) \\
\end{array}$ & $\begin{array}{l}\text { Fine } \\
\text { sand } \\
(\%)\end{array}$ & $\begin{array}{l}\text { Silt } \\
(\%)\end{array}$ & $\begin{array}{l}\text { Clay } \\
(\%)\end{array}$ & $\begin{array}{c}\text { Textural } \\
\text { class }\end{array}$ & $\begin{array}{c}\text { CEC } \\
\text { c molkg }{ }^{-1} \\
\text { soil } \\
\end{array}$ & $\begin{array}{c}E C \\
\left(\mathrm{dSm}^{-1}\right)\end{array}$ & $\begin{array}{l}\text { OM } \\
(\%)\end{array}$ & $\begin{array}{c}\text { PH } \\
(1: 2.5)\end{array}$ \\
\hline 2.59 & 30.69 & 22.58 & 44.14 & Clay & 41.08 & 10.66 & 0.63 & 8.12 \\
\hline \multicolumn{5}{|c|}{ Cations (meq/l) } & \multicolumn{4}{|c|}{ Anions (meq/l ) } \\
\hline $\mathbf{C a}^{++}$ & $\mathbf{M g}_{\xi}$ & & $\mathbf{N a}^{+}$ & $\mathbf{K}^{+}$ & $\mathrm{HCO}_{3}^{-}$ & & & $\mathrm{SO}_{4}{ }^{2-}$ \\
\hline 9.41 & 16. & & 79.48 & 0.82 & 8.30 & & & 35.36 \\
\hline \multirow{2}{*}{$\begin{array}{c}\mathrm{CaCO}_{3} \\
(\%)\end{array}$} & \multicolumn{4}{|c|}{ Macronutrients $\left(\mathrm{mgkg}^{-1}\right)$} & \multicolumn{4}{|c|}{ Micronutrients $\left(\mathrm{mgkg}^{-1}\right)$} \\
\hline & Tot: & & Available $P$ & Available K & $\mathbf{F e}$ & & & $\mathbf{Z n}$ \\
\hline 7.52 & 39. & & 9.98 & 198 & 6.88 & & & 0.70 \\
\hline
\end{tabular}

Table 1b. Physicochemical analyses of tested soil (Baher Hadoos drain)

\begin{tabular}{|c|c|c|c|c|c|c|c|c|}
\hline $\begin{array}{l}\text { Coarse } \\
\text { sand } \\
(\%) \\
\end{array}$ & $\begin{array}{l}\text { Fine } \\
\text { sand } \\
(\%)\end{array}$ & $\begin{array}{l}\text { Silt } \\
\text { (\%) }\end{array}$ & $\begin{array}{l}\text { Clay } \\
(\%)\end{array}$ & $\begin{array}{c}\text { Textural } \\
\text { class }\end{array}$ & $\begin{array}{c}\text { CEC } \\
\text { c molkg-1 } \\
\text { soil } \\
\end{array}$ & $\begin{array}{c}E C \\
\left(\mathrm{dSm}^{-1}\right)\end{array}$ & $\begin{array}{l}\text { OM } \\
(\%)\end{array}$ & $\begin{array}{c}\text { PH } \\
(1: 2.5)\end{array}$ \\
\hline 4.93 & 36.87 & 25.96 & 32.24 & Clay loam & 31.38 & 12.59 & 0.55 & 8.10 \\
\hline \multicolumn{5}{|c|}{ Cations (meq/l) } & \multicolumn{4}{|c|}{ Anions (meq/l ) } \\
\hline $\mathrm{Ca}^{++}$ & $\overline{\mathbf{M g}^{+}}$ & & $\mathrm{Na}^{+}$ & $\overline{\mathbf{K}^{+}}$ & $\mathrm{HCO}_{3}^{-}$ & & & $\mathrm{SO}_{4}{ }^{2-}$ \\
\hline 14.98 & 22.6 & & 87.45 & 0.84 & 7.96 & & & 47.42 \\
\hline \multirow{2}{*}{$\begin{array}{c}\mathrm{CaCO}_{3} \\
(\%)\end{array}$} & \multicolumn{4}{|c|}{ Macronutrients $\left(\mathrm{mgkg}^{-1}\right)$} & \multicolumn{4}{|c|}{ Micronutrients $\left(\mathrm{mgkg}^{-1}\right)$} \\
\hline & Total N & & ilable $\mathbf{P}$ & Available K & $\mathrm{Fe}$ & & & $\mathbf{Z n}$ \\
\hline 6.59 & 34.96 & & 6.36 & 185 & 5.33 & & & 0.69 \\
\hline
\end{tabular}

Table 2. Mean values of chemical properties of different irrigation water used

\begin{tabular}{|c|c|c|c|c|c|c|c|c|c|c|c|}
\hline \multirow[t]{2}{*}{ Irrigation source } & \multirow[t]{2}{*}{ pH } & \multirow{2}{*}{$\begin{array}{c}E C \\
\left(\mathrm{dSm}^{-1}\right)\end{array}$} & \multicolumn{4}{|c|}{ Cations (meq I ${ }^{-1}$ ) } & \multicolumn{4}{|c|}{ Anions (meq I $\left.{ }^{-1}\right)$} & \multirow[t]{2}{*}{ SAR } \\
\hline & & & $\mathrm{Ca}^{2+}$ & $\mathrm{Mg}^{2+}$ & $\mathrm{Na}^{+}$ & $\mathbf{K}^{+}$ & $\mathrm{CO}_{3}{ }^{2-}$ & $\mathrm{HCO}_{3}^{-}$ & $\mathrm{Cl}^{-}$ & $\mathrm{SO}_{4}{ }^{2-}$ & \\
\hline $\begin{array}{l}\text { El-Salam canal } \\
\text { Bahr Hadous }\end{array}$ & $\begin{array}{l}7.98 \\
8.03\end{array}$ & $\begin{array}{l}1.75 \\
3.31\end{array}$ & $\begin{array}{l}4.06 \\
5.85\end{array}$ & $\begin{array}{l}4.84 \\
6.29\end{array}$ & $\begin{array}{c}7.96 \\
20.15\end{array}$ & $\begin{array}{l}0.75 \\
0.95\end{array}$ & $\begin{array}{l}1.31 \\
1.82\end{array}$ & $\begin{array}{c}5.65 \\
12.31\end{array}$ & $\begin{array}{c}7.05 \\
14.33\end{array}$ & $\begin{array}{l}2.60 \\
4.78\end{array}$ & $\begin{array}{l}3.38 \\
8.18\end{array}$ \\
\hline
\end{tabular}

Table 3. Chemical properties of the humic acid substance used in the experiment

\begin{tabular}{|c|c|c|c|c|c|c|c|c|}
\hline \multicolumn{3}{|c|}{ Macronutrients (\%) } & \multicolumn{3}{|c|}{ Micronutrients (\%) } & \multirow[t]{2}{*}{ OM (\%) } & \multirow[t]{2}{*}{$E C\left(d_{S m}^{-1}\right)$} & \multirow[t]{2}{*}{ pH } \\
\hline $\mathbf{N}$ & $\mathbf{P}$ & $\mathbf{K}$ & $\mathbf{Z n}$ & Mn & $\mathbf{F e}$ & & & \\
\hline 1.98 & 0.36 & 3.40 & 32.18 & 249 & 395 & 72.00 & 2.98 & 7.63 \\
\hline
\end{tabular}




\section{Soil Samples}

Soil samples were taken before planting and after harvest from the surface layer $(0-30 \mathrm{~cm})$, air-dried, ground to pass through a 2- $\mathrm{mm}$ sieve and analyzed for some physical and chemical properties according to Sparks (1996).

\section{Statistical Analysis}

Obtained results were subjected to the proper statistical analysis by Snedcor and Cochran (1990). Bartlett's test was done to test the homogeneity of error variance. The test was not significant for all assessed traits, so the two season's data were combined.

\section{RESULTS AND DISCUSSION}

\section{Vegetative Characters}

\section{Effect of irrigation water sources}

Results in Table 4 show that application of El-Salam Canal irrigation water realized the highest significant values of vegetative characters (root length, root diameter, fresh weight (FW), dry weight (DW), fresh yield (FY), dry yield (DY), total fresh yield (TFY), total dry yield (TDY) and total chlorophyll as compared to that obtained by using irrigation water from Hadous drain. This may be due to the high salt content of both soil and irrigation water of Hadous drain which decreases the osmotic potential of the soil water and consequently reduces the availability of the soil water for plants (Khaled and Fawy, 2011).

\section{Effect of humic acid}

All growth characters were significantly $(\mathrm{P} \leq$ 0.05 ) affected by application of humic acid as shown in Table 4 . The values increased with raising humic acid rates in the two locations. The best treatment which gave maximum values was $6 \mathrm{ml} \mathrm{HA} \mathrm{l}^{-1}$. The increases were $(109,102 \%$ for root length and root diameter), (70.7, 85.7\% for FW and DW of roots), (38.5, 63.6\% for FW and DW of tops), $(20.2,26.0 \%$ for FY and DY of roots), (195.3, $175.0 \%$ for FY and DY of tops) and (25.7, 33.4\% for TFY and TDY), respectively. The increases in shoots characters may be attributed to the influence of humic acid which provides nutrient minerals that involve in plants bioactivities and finally leads to growth induction (Abdel-Mawgoud et al., 2007). The present results were similar to the results obtained by many researchers (Chen et al., 2004; Hanafy et al., 2013; El-Hamady et al, 2017).

\section{Interaction effect}

The interaction effect (El-Salam Canal irrigation water $\times$ humic acid treatments) was better than that of (Hadous Drain irrigation water $\times$ humic acid treatments) on vegetative characters of fodder beet plants expressed as root length and root diameter, FW, DW, FY, DY of fodder beet organs, TFY, TDY and Total Chlorophyll (Table 4 ). The best treatment that achieved the highest values was (El-Salam Canal irrigation water $\times 6 \mathrm{ml} \mathrm{HA}^{-1}$ ) in comparison with the other treatments. This may be due to that application of humic acid, supply fodder beet plants with readily available $\mathrm{N}, \mathrm{P}$ and $\mathrm{K}$ nutrients that are responsible for chlorophyll formation and in turn improvement of plant growth. These findings are in agreement with those of Kauser and Azam (1985), Chen et al. (2004a and b) and ElHamady et al. (2017) who reported that using humic acid as biofertilizer increases the fresh and dry weights of crop plants. Also, using potassium humate enhanced chlorophyll density (Chen and Aviad, 1990; El-Hamady et al., 2017).

\section{Yield Quality}

\section{Effect of irrigation source}

The results for yield components of fodder beet are summarized in Table 5. From results, it was inferred that the values of crude protein (CP), digestible crude protein (DCP), ash and fat (\%) in different organs of fodder beet plants, significantly decreased with applied irrigation water from Hadous drain compared to using El-Salam Canal irrigation water while proline content (in top organs) and crude fiber (CF) in fodder beet organs, took an opposite trend .This reduction in yield quality values may due to the high salt content of soil as well as salinity and sodicity of irrigation water of Hadous drain region. The present results are in harmony with those obtained by Abbas et al. (2013) and Mahboob et al. (2017) who concluded that salinity resulted in a significant reduction of the protein and fat contents. 
Table 4. Vegetative characteristics of fodder beet yield as affected by humic acid rates and irrigation water quality (combined of two seasons)

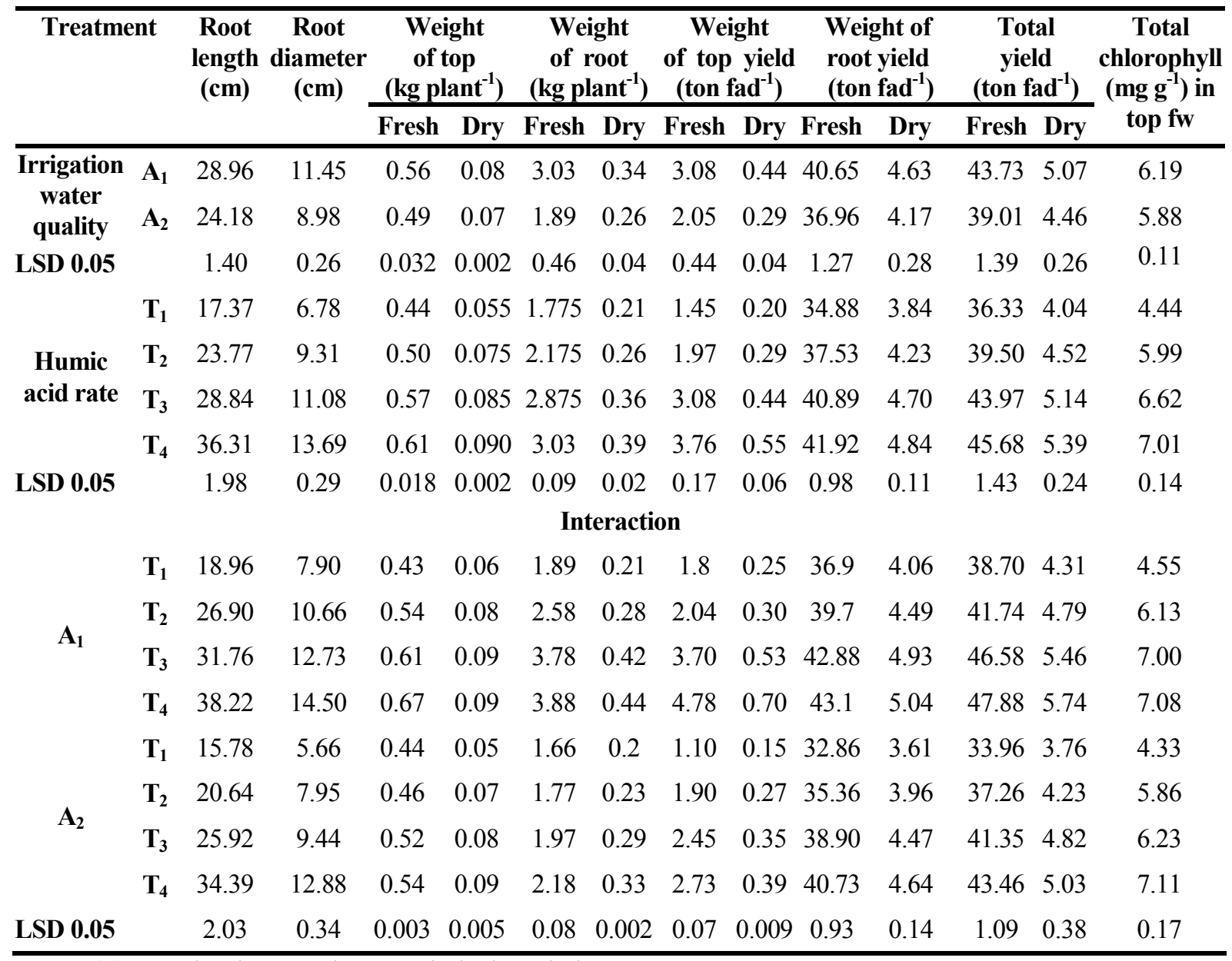

Notes: (1) $\mathrm{A}_{1}=$ El-Salam canal, $\mathrm{A}_{2}=$ Bahr hadoos drain.

(2) $\mathrm{T}_{1}=$ Control, $\mathrm{T}_{2}=800, \mathrm{~T}_{3}=1600$ and $\mathrm{T}_{4}=2400 \mathrm{ml} \mathrm{HA} 400 \mathrm{l}^{-1}$ water.

Also, other researchers reported that excessive salts in growth medium caused a reduction in uptake of essential nutrients and available water, which resulted in restricted plant height (Desoky and Merwad, 2015).

Concerning the high level of proline content of fodder plant tops (Steewart and Lee, 1974; Bar-nun and Mayber, 1977; Cavalieri and Huang, 1979) stated that saline conditions are stressful to plants for two principal reasons: First, they depress the external water potential in effect making water less readily available to the plant (an osmotic effect); Second, sodium, chloride, and other ions may disturb mineral nutrition or cause toxicities (specific ion effects). Sodicity may have the effects identified as specific ion effects. The osmotic effects of salinity are dealt with by two mechanisms: absorption of salt from the medium or synthesis of organic solutes. Higher accumulation of Proline in plants under saline conditions suggests one of the adaptive responses of fodder beet against salinity.

\section{Effect of humic acid}

Results in Table 5 show that humic acid application had significant effects on all parameters of yield quality $(\mathrm{CP}, \mathrm{DCP}, \mathrm{CF}$, fat and ash) in the two locations (El- Salam Canal and Hadous drain). Increasing humic acid rates

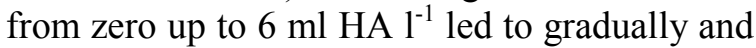
significantly increasing for the previous traits by $45.1,33.9 \%$ for $\mathrm{CP}, 12.4,23.8 \%$ for $\mathrm{CF}, 8.8$, $39.1 \%$ for ash, $77.8,64.8 \%$ for DCP and 34.4 , $72.1 \%$ for fat content in tops and roots of plant 
organs, respectively. This significant increase was probably due to the effect of humic acid on plant growth and improving physiological processes. These findings are quite analogous with the findings that obtained by Pal et al. (2004), Karakurtk et al. (2009), Devi et al. (2013) and Fathima and Denesh (2013), In addition, humic acid had direct effect on plant growth and indirect effect on physiological processes as metabolism and increases cell membrane permeability, respiration, photosynthesis, oxygen, phosphorus uptake and supplying root cell growth which promotes cell size and plant growth (Rady, 2012; Peizzeghello et al., 2013; Ouni et al.,2013).

\section{Interaction effect}

The results presented in Table 5 clearly show that the effect of humic acid rates and water irrigation types had significant effects on all yield quality attributes of fodder beet plants. It is appeared from the current results that the treatment $\mathrm{T}_{4}$ (El-Salam Canal irrigation water $\times 6$

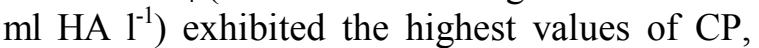
DCP, CF, fat and ash. These results are in agreement with those of Tarek et al, (2008), Mohamed (2012) and El-Sherief et al. (2013) who stated that humic acid effected directly on soil properties such as: enrichment in soil nutrients, increase of microbial population, higher cation exchange capacity (CEC) and improvement of soil structure which could led to increase macro pore spaces and removing salts from soils by leaching.

\section{Chemical Composition}

\section{Effect of irrigation source}

Results illustrated graphically in Figs. 1, 2, 3, $4,5,6,7,8,9,10,11$ and 12 and Table 6 show that using the irrigation water from El- Salam Canal gave significantly the greatest values of each of N, P, K, Fe, Mn, Zn concentrations and uptake by fodder beet plants comparing to that obtained from the application of Hadous drain irrigation water. These effects could be associated with the high salt concentrations in both irrigation water and the soil of Hadous region leading to reduce absorption of nutrients by plants which negatively affects the fertility of the soil. Similar results were obtained by Khaled and Fawy (2011).

\section{Effect of humic acid}

Increasing the applied doses of humic acid led to significant positive effects for all chemical composition parameters of fodder beet (Table 6 and Figs. 1, 2, 3, 4, 5, 6, 7, 8, 9, 10, 11 and 12).

The maximum values of chemical composition parameters expressed as N, P, K, $\mathrm{Fe}, \mathrm{Mn}, \mathrm{Zn}$ concentrations and uptake were realized with $6 \mathrm{ppm}$ humic acid treatment. These results are in accordance with those obtained by Zhen and Kui (1996), El-Bassiony et al. (2010), Obidiebube et al. (2012) and Pizzeghello et al. (2013) in respect of NPK concentration and uptake as well as trace elements, humic acids are especially important because of their freeing up nutrients in the soil and its ability to chelate micronutrients, thus increasing their bioavailability (Leonard, 2008 ; Khaled and Fawy, 2011).

\section{Interaction effect}

Concerning the effect of water irrigation sources $\times$ humic acid levels on macro and micro nutrients uptake in the tops and roots of fodder beet plants, results in Table 6 reveal that the treatment (El-Salam Canal irrigation water $\times 6$ $\mathrm{HA} \mathrm{ml} \mathrm{l}^{-1}$ ) recorded the better significant effect on the uptake of such nutrients with increments of $125.90,15.95 \%$ for $\mathrm{N}, 91.80,59.89 \%$ for $\mathrm{P}$, $112.23,22.98 \%$ for $\mathrm{K}, 82.76,9.39 \%$ for $\mathrm{Fe}$, $76.70,13.79 \%$ for $\mathrm{Mn}$ and $82.03,13.13 \%$ for $\mathrm{Zn}$ in tops and roots, respectively. These results may be attributed to the positive effect of humic acid on soil chemical, physical and biological properties and then the visible growth of plants. The studied results were in harmony with that obtained by Mackowiak et al. (2001) and Leonard (2008) which recorded that humic acid promote plant growth and induce soil microorganisms like bacteria and fungi and provide carbon as a source for the organisms, humic acid as well acting as chelating good martial and also make many nutrients available in soil such as phosphate, calcium and trace elements and finally humic acid possesses high capability in controlling soil $\mathrm{pH}$ against changes which might occurs from the use of chemical fertilizer. 
Table 5. Fodder beet yield quality and its components as affected by humic acid rates and irrigation water quality (combined of two seasons)

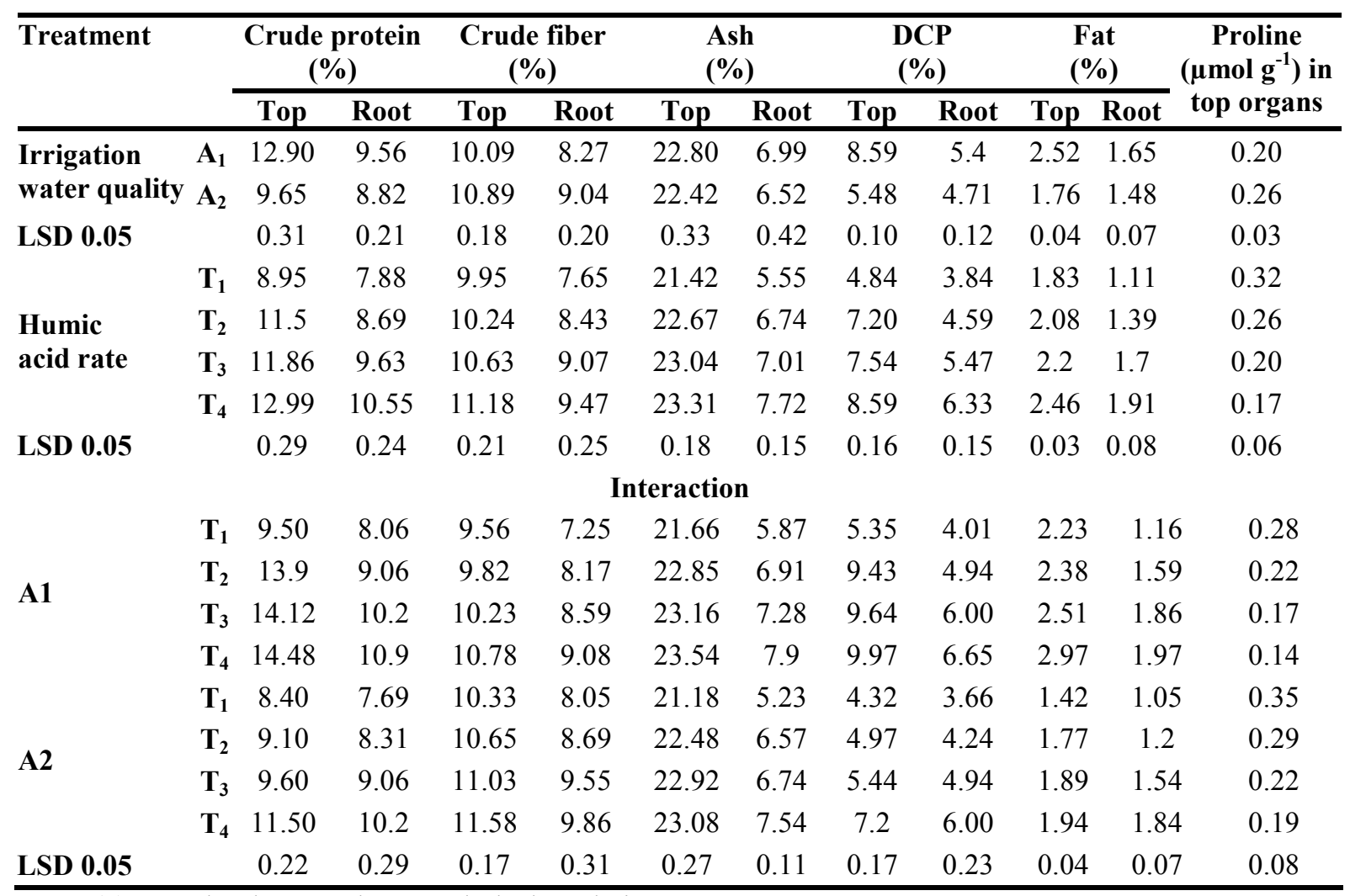

Notes:(1) $\mathrm{A}_{1}=$ El-Salam canal, $\mathrm{A}_{2}=$ Bahr hadoos drain.

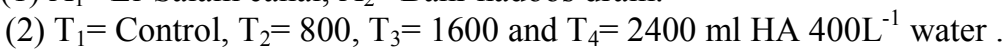

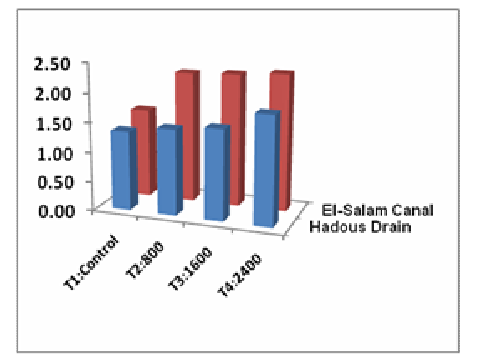

Fig. 1. N-Concentration in top

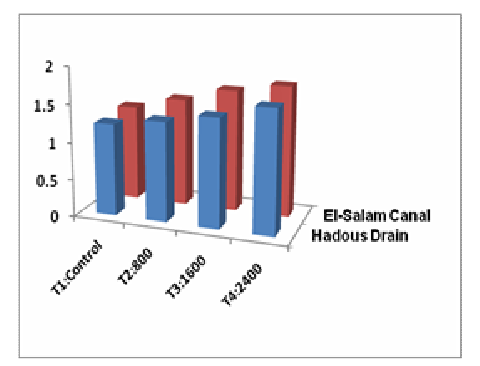

Fig. 4. N-Concentration in root

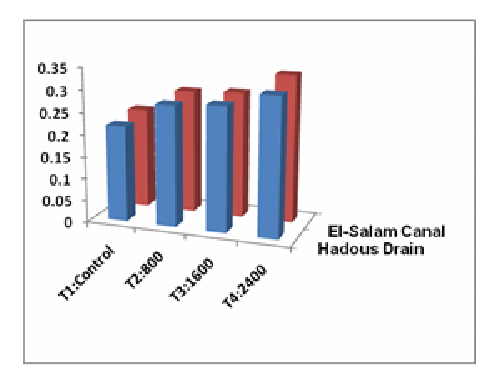

Fig. 2. P-Concentration in top

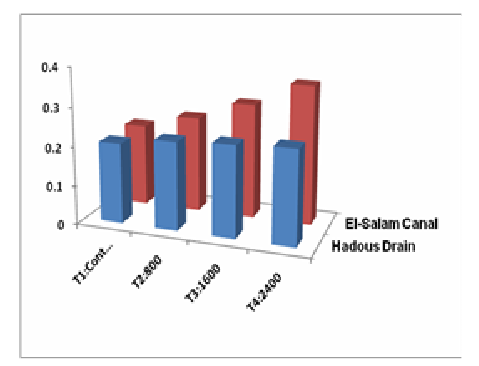

Fig. 5. P-Concentration in root

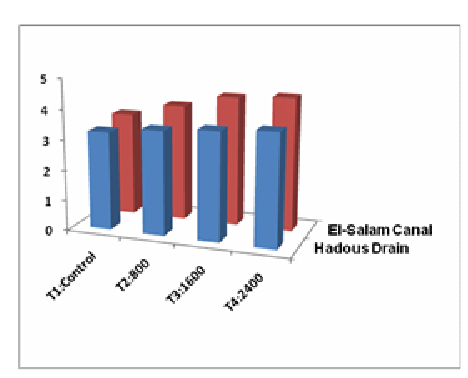

Fig. 3. K-Concentration in top

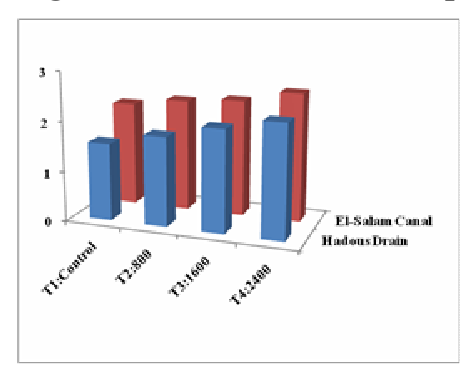

Fig. 6. K-Concentration in root

Figs. 1,2,3,4,5 and 6. Concentration of macronutrients in fodder beet organs as affected by humic acid rates and irrigation water quality (combined of two seasons) 


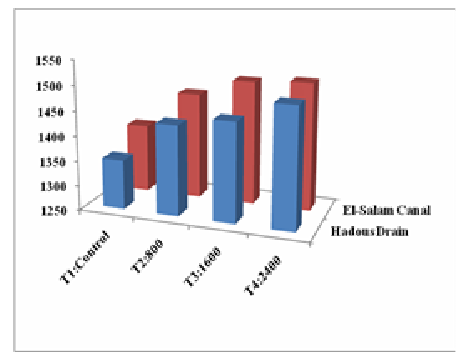

Fig. 7. Fe-Concentration in top

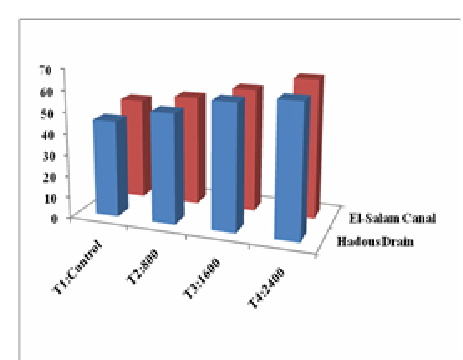

Fig. 10. Fe-Concentration in root

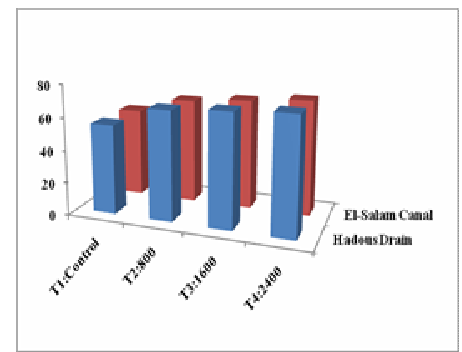

Fig. 8. Mn-Concentration in top

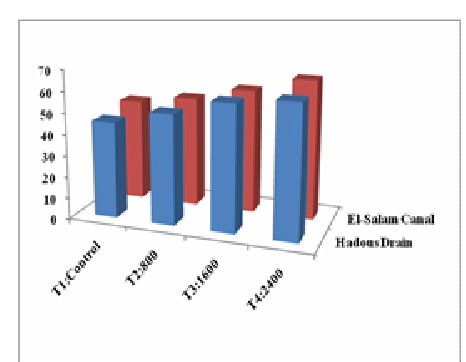

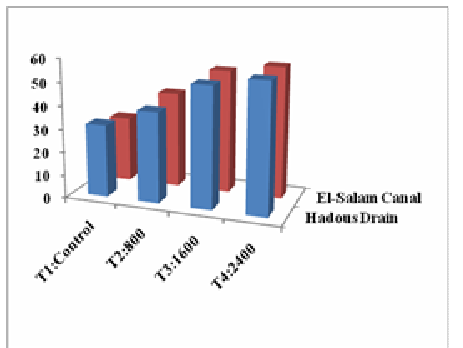

Fig. 9. Zn-Concentration in top

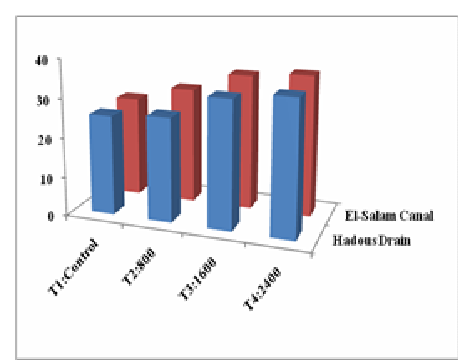

Figs. 7,8,9,10,11 and 12. Concentration of micronutrients in fodder beet organs as affected by humic acid rates and irrigation water quality (combined of two seasons)

Table 6. Macro-micronutrients uptake by fodder beet organs as affected by humic acid rates and irrigation water quality (combined of two seasons)

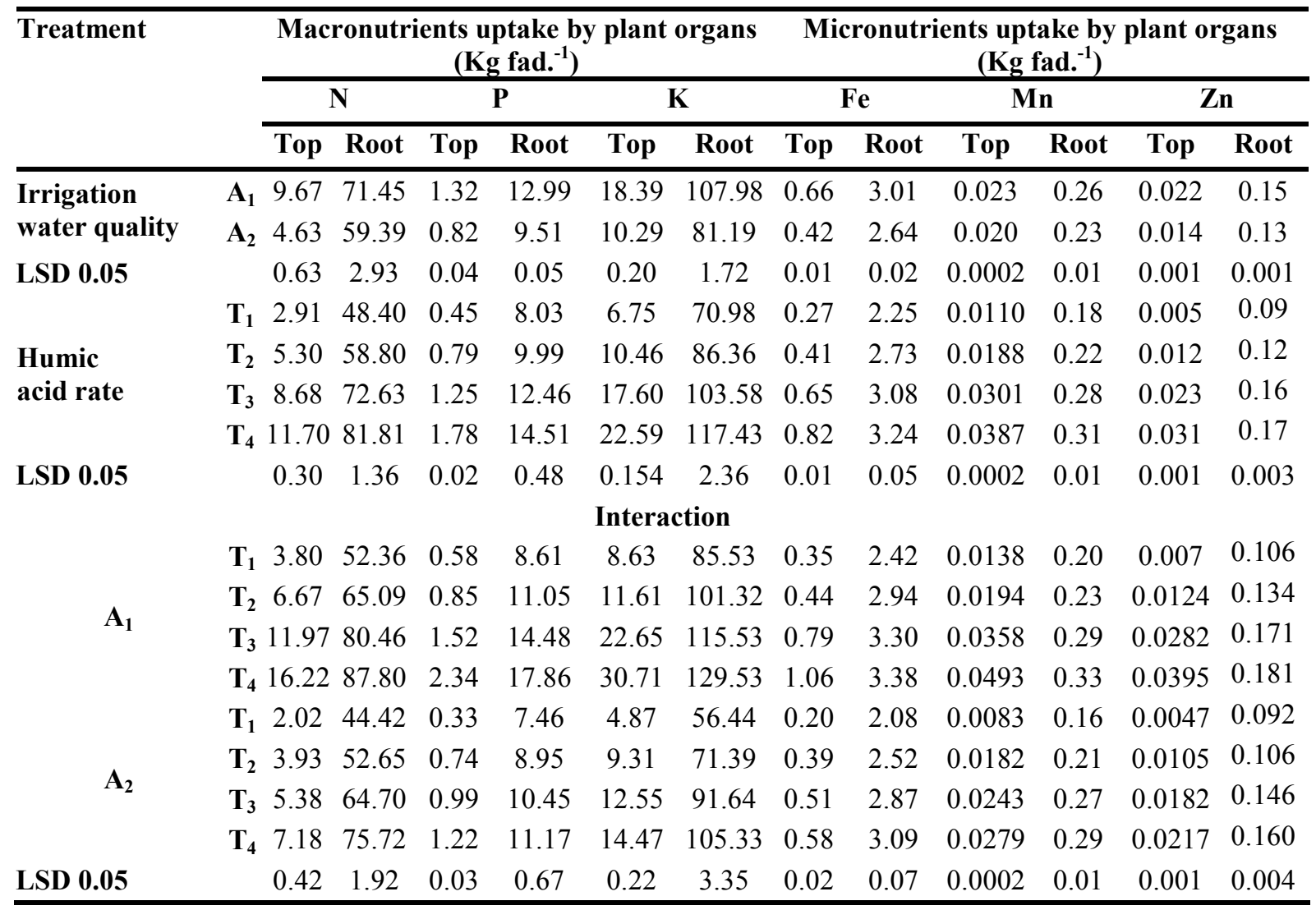

Notes: (1) $\mathrm{A}_{1}=$ El-Salam canal, $\mathrm{A}_{2}=\mathrm{Bahr}$ hadoos drain.

(2) $\mathrm{T}_{1}=$ Control, $\mathrm{T}_{2}=800, \mathrm{~T}_{3}=1600$ and $\mathrm{T}_{4}=2400 \mathrm{ml} \mathrm{HA} 400 \mathrm{~L}^{-1}$ water. 


\section{Chemical Properties of Soil After Fodder Beet Harvested}

\section{Soil pH}

Soil $\mathrm{pH}$ is an important chemical property because it affects on the availability of nutrients to plants and the activity of soil microorganisms. The effects of application the humic acid rates on soil $\mathrm{pH}$ are presented in Table 7. The results show that the soil $\mathrm{pH}$ decreased with increasing the levels of humic acid in both two locations (El-Salam canal or Baher hados drain). The lowest value of soil pH was 7.56 for soil of Baher hados drain and 7.94 for soil of El-Salam canal. The applications of HA at rate of $6 \mathrm{ml}^{-1}$ of irrigation water lowered the soil $\mathrm{pH}$ by 0.55 units for Baher hados soil versus 0.20 units for El-Salam canal soil. This may due to the higher buffering capacity of El-Salam canal soil. This result is corresponding with those obtained by El-Sherief et al. (2013).

\section{Soil salinity (EC)}

From the listed results in Table 7, it could be conclude that the EC values of the soil decreased gradually due to the application of humic acid at different rates by irrigation either at El-Salam irrigation canal or Baher hados drain compared to the control. This decline mainly due to release $\mathrm{H}^{+}$humic acid into the soil solution, where its position was replaced by salt cation, then decrease the salt concentration in the solution so that the value of EC was reduced.
Furthermore, this could be due to the role of humic acid in improving soil aggregation, porosity (increasing macro pore spaces) and water movement leaching the excessive soluble salts. The lowest EC values are obtained with applied treatment $\mathrm{HA}$ at rate of $6 \mathrm{ml} \mathrm{l}^{-1}$ of irrigation water $\left(\mathrm{T}_{4}\right)$ at the two studied locations (El-Salam canal, Baher hados drain). These results were similar to those obtained by Tarek et al. (2008), Mohamed (2012) and El-Sherief et al. (2013).

\section{Soil cation exchange capacity, macro and micronutrients contents}

Results presented in Table 7 indicate that application of humic acid has been identified to raising the soil $\mathrm{CEC}$, macro and micronutrients content. This was because of the increase of cations at the mineral surface and between minerals.

Concerning micronutrients available from the aforementioned results, it could be concluded that $\mathrm{Fe}, \mathrm{Mn}$ and $\mathrm{Zn}$ tend to increase in studied soil with increasing the rates of humic acid. This may be due to the decrease of $\mathrm{pH}$ values with increasing the humic acid levels at the two locations (El-Salam canal or Baher hados drain).Under neutral soil $\mathrm{pH}$, nutrients are available in considerable amounts. However, if the soil $\mathrm{pH}$ is more than 8.0, nitrogen, iron, manganese, boron, copper, and zinc will be less available to plants (Tan, 1998).

Table 7. Chemical analysis of tested soil after harvest fodder beet yield

\begin{tabular}{|c|c|c|c|c|c|c|c|c|c|c|}
\hline \multirow[t]{2}{*}{ Location } & \multirow[t]{2}{*}{$\begin{array}{c}\text { Rate of } \\
\text { humic acid }\end{array}$} & \multirow[t]{2}{*}{$\begin{array}{c}\text { pH } \\
(1: 2.5)\end{array}$} & \multirow[t]{2}{*}{$\begin{array}{c}\mathrm{EC} \\
\left(\mathrm{dSm}^{-1}\right)\end{array}$} & \multirow[t]{2}{*}{$\begin{array}{c}\text { CEC c mol } \\
\mathrm{kg}^{-1} \text { soil }\end{array}$} & \multicolumn{3}{|c|}{$\begin{array}{c}\text { Macronutrients } \\
\left(\mathrm{mg} \mathrm{kg}^{-1}\right)\end{array}$} & \multicolumn{3}{|c|}{$\begin{array}{l}\text { Micronutrients } \\
\left(\mathrm{mg} \mathrm{kg}^{-1}\right)\end{array}$} \\
\hline & & & & & $\mathbf{N}$ & $\mathbf{P}$ & $\mathbf{K}$ & $\mathbf{F e}$ & Mn & Zn \\
\hline \multirow{4}{*}{ EI-Salam canal } & control & 8.10 & 10.33 & 41.18 & 41.98 & 10.14 & 199 & 7.03 & 2.47 & 0.78 \\
\hline & 800 & 8.01 & 9.78 & 45.92 & 42.89 & 10.83 & 201 & 7.50 & 2.87 & 0.82 \\
\hline & 1600 & 7.99 & 9.16 & 46.76 & 44.66 & 11.35 & 203 & 7.90 & 2.92 & 0.86 \\
\hline & 2400 & 7.94 & 8.59 & 48.02 & 45.03 & 12.29 & 210 & 8.01 & 2.99 & 0.88 \\
\hline \multirow{4}{*}{ Hadous drain } & control & 8.10 & 12.26 & 31.51 & 37.81 & 7.10 & 190 & 5.98 & 2.03 & 0.73 \\
\hline & 800 & 7.94 & 11.58 & 33.12 & 39.8 & 7.55 & 193 & 6.39 & 2.14 & 0.78 \\
\hline & 1600 & 7.75 & 10.82 & 36.81 & 42.85 & 8.28 & 198 & 6.70 & 2.21 & 0.82 \\
\hline & 2400 & 7.56 & 10.31 & 38.52 & 43.9 & 9.93 & 203 & 7.98 & 2.35 & 0.86 \\
\hline
\end{tabular}




\section{Conclusion}

Generally, the present study suggests using humic acid at high rate $\left(2400 \mathrm{ml} 400 \mathrm{l}^{-1}\right.$ water, $\mathrm{T}_{4}$ ) with El-Salam canal or Baher Hados drain which improve soil chemical properties and thus increases the productivity of saline soil as well as improving both of growth and quality characters of fodder beet plants.

\section{REFERENCES}

Abbas, G., M. Saqib, Q. Rafique, M.A. UrRahman, J. Akhtar, M.A. Ul-Haq and M. Nasim (2013). Effect of salinity on grain yield and grain quality of wheat (Triticum aestivum L.). Pak. J. Agric. Sci., 50: 185-189

Abdel-Gwad, M.S.A., T.K.A. El-Aziz and M.A. A. El-Galil (2008). Effect of intercropping wheat with fodder beet under different levels of N-application on yield and quality. Ann. Agric. Sci. Cairo, 53 (2): 353-362.

Abdel-Mawgoud, A.M.R., N.H.M. El-Greudy, Y.I. Helmy and S.M. Singer (2007). Responses of tomato plants to different rates of humic based fertilizer and NPK fertilization. J. Appl. Sci. Res., 3 (2): 169-174.

Akyıldız, A.R. (1983). Yemler Bilgisi ve Teknolojisi. Ankara Üniv. Zir. Fak. No., 868, Ankara.

Albayrak, S. and N. Çama (2006). Yield components of fodder beet (Beta vulgaris var. crassa Mansf.) under the Middle Black Sea region conditions. Tarım Bilim. Derg., 12 (1): 65-69.

Albayrak, S., M. Türk and O. Yüksel (2009). Effects of phosphorus fertilization and harvesting stages on forage yield and quality of woolypod vetch. Turkish J. Field Crops, 14 (1): 30-40.

Atiyeh, R.M., C.A. Edwards, J.D. Metzger, S. Lee and N.O. Arancon (2002). The influence of humic acids derived from earth worm processed organic wastes on plant growth. Bioresource Technol., 84:7-14.

Bar-Nun, N. and A.P. Mayber (1977). Salinity stress and the content of proline in roots of Pisum sativum and Tamarix tetragyna. Ann. Bot., 41: 173-179.
Cavalieri, J.A. and A.H.C. Huang (1979). Evaluation of proline accumulation in the adaptation of diverse species of marsh halophytes to the saline environment. Ame. J. Bot., 66 (3): 307-312.

Chen, Y., D.E. Nobilm and T. Avlad (2004). Stimulatory effects of humic substances on plant growth. In: Soil organic matter in sustainable agriculture (Magdoff F., Weil RR, eds). CRC Press, NY, USA., 103-129.

Chen Y., C.E. Clapp and H. Magen (2004a). Mechanisms of plant growth stimulation by humic substances: The role of organic-iron complexes. Soil Sci. and Pl. Nut., 50 : 10891095.

Chen, Y., M. Nobili and T. Aviad (2004b). Stimulatory effect of humic substances on plant growth. In: Magdoft F., Ray R. (eds): Soil Organic Matter in Sustainable Agric.. CRC Press, Washington.

Chen, Y. and T. Aviad (1990). Effects of humic substances on plant growth. In: Humic Substances in Soil and Crop Science: Selected Readings. P. MacCarthy, C.E. Clapp, R.L. Malcolm and P.R. Bloom (eds.), American Society of Agronomy Inc., Soil Science of America, Inc., Madison, WI, 161186.

Church, D.C. (1979). Digestive Physiology and Nutrition of Rumi- nant, 1 Corvallis, O and B Books Inc.

David, PP. (1991). Effects of applied humic acids on yield, growth, nutrient accumulation content in selected vegetable crops and soil interactions that reduce their effectiveness. Dissertation Abstracts Int. B. Sci. and Eng., 52 (3): $1136-1137$.

Desoky, E.M. and A.M. Merwad (2015). Improving the salinity tolerance in wheat plants using salicylic and ascorbic acids. J. Agric. Sci., 10: 203-217.

Devi, C.P., D.K. Singh and S.K. Jain (2013). Effect of foliar feeding of micronutrients on growth and yield of chilli (Capsicum annuum var. accuminatum L.) cultivar Pant C-3. Pantnagar J. Res., 11 (1): 105- 111. 
El-Bassiony, A.M., Z.F. Fawzy, E.H. Abd ElSamad and G.S. Riad (2010). Growth, yield and fruit quality of sweet pepper plants (Capsicum annuum L.) as affected by potassium fertilization. J. Ame. Sci, 6: 12 .

El-Desuki, M. (2004). Response of onion plants to humic acid and mineral fertilizers application. Ann. Agric. Sci., Moshtohor, 42 (4): 1955-1964.

El-Hamady, M.M., A.G. Baddour, M.M. Sobh, H.M. Ashour and H.H. Manaf (2017). Influnce of mineral fertilization with $\mathrm{K}$ humate, Amino acid and sodium selenite on growth, chemical composition, yield fruit quality of Sweet Pepper plant. Mid. East J. Agric. Rec., 6 (2) : 433-447.

El-Sherief, A.A., M.F. Tantawy and Kh.A. Shaban (2013). Improving newly reclaimed sandy saline soil properties and its productivity of sudan grass by organic, bio and mineral-N fertilization. $2^{\text {nd }}$ Int. Conf. On Environ. Studies and Res. (Nat. Res. and Future Challenges), Environ. Studies and Res. Inst. (ESRI), Sadat City Univ., Egypt, 25 (27): 249-266

Fathima, P.S. and G.R. Denesh (2013). Influence of humic acid spray on growth and yield of chilli (Capsicum annuum L.). Int. J. Agric. Sci., 9 (2): 542-546.

Hanafy, A.A.H.D., S.A.F. Hamoda and M.G. Alobaidy (2013). Effect of putrescine and humic acid on growth, yield and chemical composition of cotton plants grown under saline soil condition. Ame.-Eurasian J. Agric. and Environ. Sci., 13(4): 479-497.

Karakurtk, Y., H. Unlu and H. Padem (2009). The influence of foliar and soil fertilization of humic acid on yield and quality of pepper. Acta Agric. Scandinavica Section B Soil and Plant Sci., 59 : 233-237.

Kauser, A.M. and F. Azam (1985). Effect of humic acid on corn seedling growth. Environ. and Experim. Bot., 25 : 245-252.

Khaled, H. and H.A. Fawy (2011). Effect of different levels of humic acids on the nutrient content, plant growth, and soil properties under conditions of salinity. Soil and Water Res., 6 (1): 21-29.
Leonard, A.G. (2008). Humic acid: 100\% Natural, Many Uses. Goldend Harvest organic. LLCTM.

Maas, E.Y. (1986). Crop tolerance to soil and water. Prospects for Biosaline Res. Proceedings of the US-Pakistan Biosaline Research Workshop, 22-26 September, 1985, Karachi, Pakistan, R. Ahmed and A. San Pietro (eds), Pub!. Dept. Bot. Univ. Karachi, Karachi, Pakistan, 205-219

Mackowiak, C.L, P.R. Grossl and B.G. Bugbee (2001). Beneficial effect of humic acid on micronutrients availability of wheat. Soil Sci. Soc. Amer. J., 56: 1744- 1750.

Mahboob, W., M.A. Khan and M.U. Shirazi (2017). Characterization of salt tolerant wheat (Triticum aestivum) genotypes on the basis of physiological attributes. Int. J. Agric. Biol., 19: 726-734

Martin, R.C., H.D. Voldeng and D.L. Smith (1990). Intercropping soybean for silage in a cool temperate region: yield, protein and economic effects. Field Crops Res., 23: $295-$ 310.

Mohamed, W.H. (2012). Effect of humic acid and calcium forms on dry weight and nutrient uptake of maize plant under saline condition. Aust. J. Basic and Appl. Sci., 6 (8): $597-604$.

Neri, D., E.M. Lodolini, G. Savini, P. Sabbatini, G. Bonanomi and F. Zucconi (2002). Foliar application of humic acid on strawberry (cv. Onda). Proc. 1S on foliar nutrient. Eds. M. Tagliavini, Acta Hort., 594: 297-302.

Niazi, B.H., J. Rozema, R.A. Broekman and M. Salim (2000). Dynamics of growth and water relations of fodder beet and sea beet in response to salinity. J. Agron. and Crop Sci., 184 : 101-109.

Obidiebube, E.A., P.G. Eruotor, S.O. Akparobi, S.O. Emosaariue, U.A. Achebe and P.E. Kator (2012). Response of four cultivars of pepper (Capsicum frutescens $\mathrm{L}$.) to different levels of $\mathrm{N}, \mathrm{P}$ and $\mathrm{K}$ fertilizer in rainforest Agro-ecological zone. Int. J. Agric. Sci., 2 (12): 1143-1150. 
Ouni, Y., T. Ghnaya, F. Montemurro, Ch. Abdelly and A. Lakhdar (2013). The role of humic substances in mitigating the harmful effects of soil salinity and improve plant productivity. Int. J. Pl. Prod., 8 (3): 353- 374.

Özen, N., A. Çakır, S. Ha_imo_lu, S.ve Aksoy (1993). Yemler Bilgisi ve Yem Teknolojisi Ders Notlar1: 50. Atatürk Univiversitesi Erzurum.

Padem, H., A. Ocal and R. Alan (1999). Effect of humic acid added to foliar fertilizer on quality and nutrient content of eggplant and pepper seedlings. Acta Hort., 491: 241-246.

Pal, R.K., T.K. Behera, N. Sen and M. Singh (2004). Response of bell pepper (Capsicum annum) cultivars to foliar application of magnesium, boron and zinc. Veg. Sci., 31 (1): $40-44$.

Pizzeghello, D., O. Francioso, A. Ertani, A. Muscolo and S. Nardi (2013). Isopentenyladenosine and cytokinin-like activity of different humic substances. J. Geochem. Ex., 129: 70-75.

Rady, A.A. (2012). A novel organo-mineral fertilizer can mitigate salinity stress effects for tomato production on rclamied saline soil South Afr. J. Bot., 81 : 8-14.

Rahmat, U.K., A. Rashid, M.S. Khan and E. Ozturk (2010). Impact of humic acid and chemical fertilizer application on growth and grain yield of rainfed wheat (Truticum aestivum, L.). Paki. J. Agric. Res., 23 /N (34):113-121.

Sarhan, G.M.A and S.A. Ismail (2003). Response of fodder beet (Beta vulgaris L.) to different sources and levels of nitrogen under two levels of potassium fertilization. Ann. Agric. Sci, Moshtohor, 41(1): 461-473.
Sndecor, G.W. and W.G. Cochran (1990). Statistical Methods $7^{\text {th }}$ Ed. IOWA, State Univ., USA.

Sparks, D.L. (1996). Methods of Soil Analysis, part 3-chemical methods, ( $\left.{ }^{\text {nd }} E d.\right)$, Agron. 9: ASA, Ins., Madison, Wisc., USA.

Steewart, G.R. and J.A. Lee (1974). The role of proline accumulation in halophytes. Planta., 120: 279-289.

Tan, K.H. (1998). Principles of Soil Chemistry. $3^{\text {rd }}$ Ed. 521

Tarek, G.A., B.T. Alaedeen, M.S. Hani, I.H. Buteos and A.A. Yasin (2008). Salt removal efficiency as influenced by phyto-melioration of salt affected soils. J. Food, Agric. and Environ., 6 (3 and 4): 456- 460.

Türk, M., S. Albayrak, C. Balabanlý and O. Yuksel (2009). Effects of fertilization on root and leaf yields and quality of forage turinp (Brassica rapa L.). J. Food, Agric. nad Environ., 7 (3-4): 339-342.

Ulukan, H. (2008). Humic acid application into field crops cultivation. Kahraman Maras Sutcu Imam Univ., J. Sci. Eng., 11 (2): 119-128.

Varnin, Z. and R. Pinton (2001). Direct versus indirect effects of soil humic substances on plant growth and nutrition. In: The rhizosphere: biochemistry and organic substances at the soil-plant interface (Pinton R., Varanini Z., Nannipieri P., eds). Marcel Dekker Inc, NY, USA, 141-157.

Westerman, E. (1990). Soil Testing and Plant Analysis, ( $3^{\text {rd }}$ Ed.), Monograph No.3,Soc.,of Am. Book Series, SSA, Ins., Madison, Wisc., USA.

Zhen D.C. and J.H.J. Kui (1996). Studies on fertilizer application levels of seedling stage of eggplant raised with mixed media. China Veg., 4:16-18. 


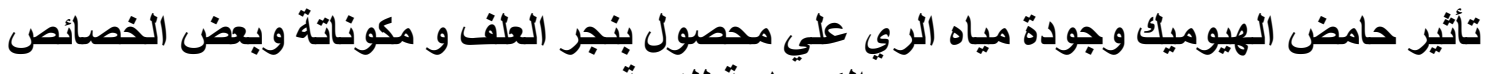
الكيميائية للتربة بولة

أشرف محمد جوده طه عويس ' ـ فاطمة شهاب الدين احمد إسماعيل'r

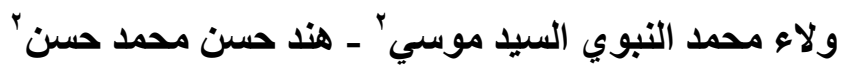

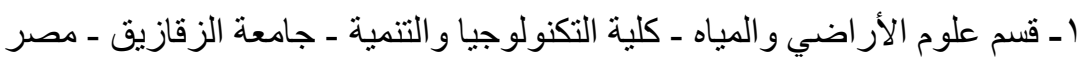

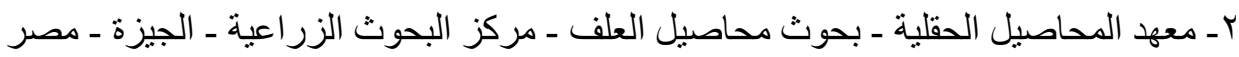

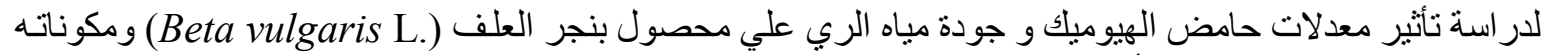

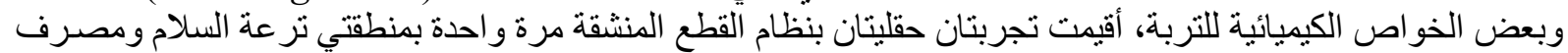

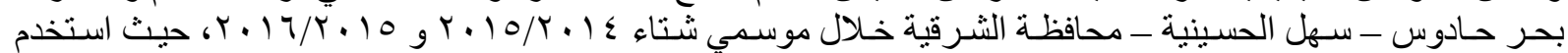

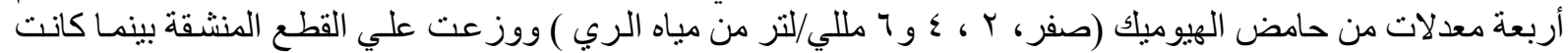

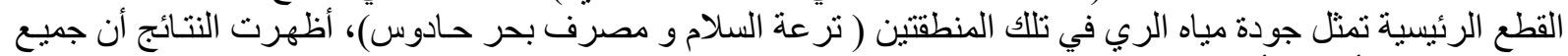

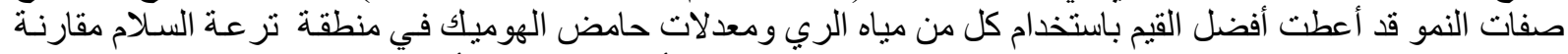

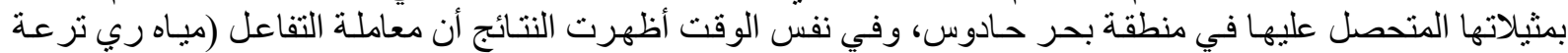

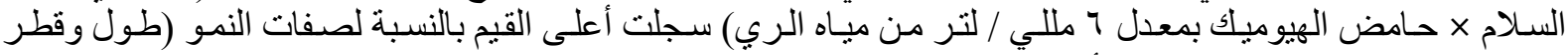

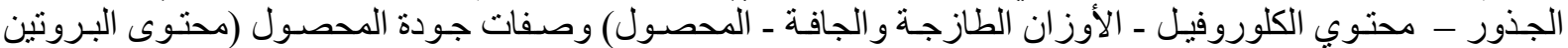

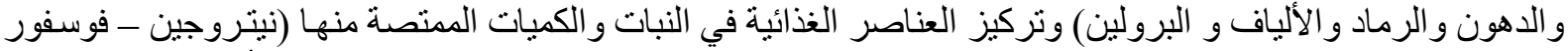

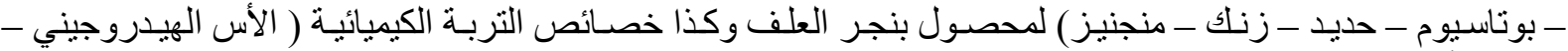
تركيز الأملاح ـ السعة التبادلية الكاتيونية للتربة ـ حالة العناصر الغذائية الكبرى و الصغرى). 